\title{
Perbaikan Lingkungan Dengan Penanaman Mangrove Berbasis Komunitas Sebagai Dukungan Terhadap Perikanan Berkelanjutan: Studi Kasus Di Dusun Binanga Sangkara, Maros, Sulawesi Selatan
}

\section{Environmental Rehabilitation Through Community-Based Mangrove Replanting Action As A Sustainable Fisheries Campaign: A Case Study At Binanga Sangkara, Maros, South Sulawesi}

\author{
Achmad Fuad Fathurrahman ${ }^{1}$, Idham Malik ${ }^{2 *}$, Amriana ${ }^{2,3}$ \\ ${ }^{1}$ Jurusan Ilmu Lingkungan, Fakultas Kehutanan dan Ilmu Lingkungan, Universitas Haluoleo, \\ Kampus Drs. H. Abdullah Silondae, Jl. Mayjend S. Parman, Kemaraya, Kendari 93121, \\ Indonesia. \\ ${ }^{2}$ Program Akuakultur WWF Indonesia. Jl. Pemuda 1 No. 2, Kel Renon, \\ Denpasar Selatan, Denpasar, 80226, Indonesia. \\ ${ }^{3}$ Jurusan Perikanan, Fakultas Ilmu Kelautan dan Perikanan, Universitas Hasanuddin, \\ Jl. Perintis Kemerdekaan Km. 10 Tamalanrea, Makassar 90245, Indonesia. \\ Corresponding author*imalik@wwf.id
}

Submited: 22 June 2021 Revised: 05 July 2021 Accepted: 22 July 2021 Publish: 31 July 2021

\begin{abstract}
Abstrak
Mangrove merupakan ekosistem unik yang umumnya terletak di pesisir pantai, memiliki peran yang sangat vital bagi makhluk hidup baik yang menghuni di dalam maupun di sekitar ekosistem tersebut. Sebagai pemilik hutan mangrove terbesar di dunia, Indonesia memiliki potensi besar baik untuk perikanan berkelanjutan maupun kesejahteraan masyarakat. Dalam rangka melestarikan ekosistem mangrove untuk perikanan yang berkelanjutan, perbaikan lingkungan melalui program rehabilitasi mangrove menjadi penting. WWF Indonesia bekerjasama dengan PT. Bogatama Marinusa (PT. Bomar) melaksanakan program rehabilitasi mangrove untuk mendukung sertifikasi udang ASC (Aquaculture Stewardship Council). Kegiatan tersebut dilaksanakan pada tahun 2019 di Binangasangka, Maros, Sulawesi Selatan. Program tersebut dilaksanakan dalam beberapa tahapan yaitu perencanaan, konsolidasi kepada masyarakat, sosialisasi dan dukungan lokal, penyiapan benih, penanaman, serta monitoring dan evaluasi. Seluruh program telah melibatkan beberapa komunitas peduli lingkungan lokal, terutama komunitas pemuda, dan telah berkolaborasi dengan pemangku kepentingan lokal yang signifikan yaitu Balai Penelitian Budidaya Air Payau Maros dan Universitas Teknologi Sulawesi, serta merangkul masyarakat setempat. Pada akhirnya, sekitar 24 ribu bibit mangrove telah ditanam dan luasnya mencapai 1 hektar. Dari jumlah tersebut, benih yang berhasil bertahan telah mencapai $74 \%$ dan mudah-mudahan mapan di masa yang akan datang. Keseluruhan kegiatan tersebut diharapkan dapat memberikan kontribusi tidak hanya memperluas cakupan mangrove di wilayah pesisir, tetapi juga menjadi sarana pendidikan tentang kesadaran lingkungan kepada generasi muda.
\end{abstract}

Kata kunci: mangrove, rehabilitasi, masyarakat, Maros.

\section{Abstract}

Mangrove, a unique ecosystem commonly situated on the coast, has a very vital role for the living creatures both inhabiting in and around the ecosystem. As the biggest mangrove forest holder in the world, Indonesia owns its great potential for both sustainable fisheries and community welfare. In order to preserve the mangrove ecosystem for sustainable fisheries, environmental improvement through mangrove rehabilitation program is important. WWF Indonesia collaborated with PT. Bogatama Marinusa (PT. Bomar) implement a mangrove rehabilitation program to support ASC (Aquaculture Stewardship Council) shrimp certification. The activity was implemented on 2019 at Binangasangka, Maros, South Sulawesi. The program was implemented in several steps namely planning, consolidation to communities, socialization and local support, seed preparation, planting, and monitoring and evaluation. The whole program has engaged multiple local environment-concern communities, especially youth community, and have collaborated significant local stakeholders namely the Institute of Brackish Aquaculture Research of Maros and the Technology University of Sulawesi, as well embraced local society. In the end, about 24 thousand mangrove seeds have been planted and covering up to 1 hectare. From the mentioned number, the successfully survived seeds have reached $74 \%$ and hopefully wellsettled in future. The overall activities were expected to contribute not only expanding mangrove 
coverage in coastal area, but also being the educational tools about environmental awareness to young generation.

Keywords: mangrove, rehabilitation, community, Maros.

\section{PENDAHULUAN}

Indonesia adalah negara dengan luasan mangrove terbesar di dunia dengan luas 3,5 juta hektar atau sekitar $20 \%$ dari total lahan dunia (FAO 1985; Gielsen dkk., 1991; Spalding dkk.,1997). Luasan ekosistem mangrove ini mudah ditemukan di kawasan pesisir, menyimpan potensi besar serta memainkan peran yang sangat vital baik di sektor perikanan maupun sektor lainnya. Ekosistem mangrove menjadi habitat berbagai spesies hewan dan tumbuhan di dalamnya. Selain itu, ekosistem mangrove menjadi lokasi peneluran (hatching ground) dan pemeliharan benih (nursery ground) bagi beberapa komoditas perikanan penting.

Bahkan, ekosistem mangrove berpotensi meminimalisir dampak yang besar dari fenomena laut seperti banjir rob dan tsunami, memiliki kemampuan untuk menyimpan karbon (carbon preserving) yang tinggi jika dibandingkan dengan ekosistem lainnya, hingga menjadi objek wisata bahari (Spaninks dan Beukering, 1997; Manassrisuksi dkk., 2001; Ng dan Sivasothi, 2001; Ong, 2002; Setiawan dkk., 2003). Sektor perikanan Indonesia sangat potensial untuk dikembangkan menjadi salah satu andalan ekonomi nasional. Sektor ini didukung oleh sumberdaya alam yang sangat melimpah. Perikanan di Indonesia dapat mengakomodir kehidupan masyarakat pesisir dengan berbagai bentuk mata pencaharian terkait, menyediakan sumber nutrisi penting bagi manusia, hingga menyajikan berbagai potensi wisata bahari (Asiati dan Nawawi, 2017; Anggraeni dkk., 2020). Dengan luas wilayah laut yang dapat dikelola sebesar 5,8 juta $\mathrm{km}^{2}$ (Bappenas, 2018) dan status Indonesia negara sebagai kepulauan terbesar di dunia (Purwanto dan Mangku, 2016) menjadikan perikanan menjadi sangat strategis.

Sulawesi Selatan merupakan salah provinsi di Indonesia dengan potensi sumberdaya perikanan yang sangat tingi. Perikanan tangkap Sulawesi Selatan telah berhasil mengumpulkan sekitar 340 ribu ton pada 2018, sedangkan budidaya laut dan pesisir sebanyak lebih dari 3,5 juta ton. Khusus perikanan budidaya, tercatat lebih dari 148 ribu hektar lahan 
termanfaatkan untuk usaha budidaya. Sumberdaya perikanan tersebut menjadi sumber pendapatan penting bagi hingga 46 ribu rumah tangga perikanan laut dan 85 ribu rumah tangga budidaya pesisir dan laut (BPS Sulsel, 2019).

Begitu pentingnya peranan ekosistem mangrove sayangnya tidak diiringi dengan kondisi mangrove saat ini. Di Indonesia, dalam kurun waktu tiga dekade terakhir, terdapat lebih dari $50 \%$ wilayah hutan mangrove yang hilang (Fitri dan Anwar, 2014). Khusus kasus di Sulawesi Selatan, kondisi hutan mangrove terus mengalami degradasi cukup besar. Pada 1950-an, masih terdapat sekitar 110 ribu hektar tutupan mangrove (Gielsen dkk., 1991) dan pada 2014 diperkirakan hanya tersisa hampir 29 ribu hektar. Bahkan, dari jumlah tersebut hanya sekitar 5 ribu hektar yang masuk dalam kategori baik (Setiawan, 2015). Penyebab penurunan luasan hutan mangrove sebagian besar berasal dari aktivitas manusia seperti alih fungsi lahan jadi perkebunan sawit, ekstraksi kayu bakau untuk kayu arang, pembersihan lahan untuk tambak, dan dirambah jadi perladangan ilegal masyarakat (Syamsu dkk., 2012; Hafni, 2016).
Upaya pelestarian ekosistem mangrove perlu dilakukan untuk memulihkan dan mengembalikan fungsi perlindungan, pelestarian dan fungsi produksinya. Rehabilitasi hutan mangrove dapat dilaksanakan dengan melakukan penghijauan menggunakan teknik yang tepat. Selain penguasaan teknik penanaman, formasi jenis tumbuhan yang membentuk atau jenis penyususun hutan mangrove pada lokasi yang akan dilakukan penanaman juga perlu dipelajari (Biswas dkk., 2009). Ekosistem mangrove umumnya tersusun dari tumbuhan penyusun utama, antara lain Avicennia sp., Rhizophora sp., Sonneratia sp., atau Bruguiera sp. (Supriharyono, 2007). Tahapan implementasi rehabilitasi hutan mangrove menurut Sugiarto dan Ekariyono (1996) meliputi pengadaan bibit, seleksi bibit, persemaian dan media semai, pengangkutan bibit, penanaman, dan pemeliharan.

Rehabilitasi mangrove dapat dilakukan dengan melibatkan berbagai latarbelakang masyarakat, seperti warga setempat yang menerima langsung manfaat jasa ekosistem maupun di luar dari masyarakat tersebut. Berbagai komunitas, baik yang berlatar belakang pemerhati lingkungan maupun bukan, 
Journal of Aquaculture Science

DOI: https://doi.org/10.31093/joas.v6i1IS.166
July 2021 Vol 6 Issue Spesial: 134-147

Online pada http://joas.co.id ternyata juga memiliki perhatian terhadap kondisi ekosistem mangrove dan ketertarikan untuk dapat terlibat dalam upaya rehabilitasi hutan mangrove. Dengan pendekatan yang tepat dan koordinasi yang baik, rehabilitasi ekosistem mangrove dapat melibatkan peran aktif tidak hanya masyarakat setempat, melainkan juga komunitas sehingga kegiatan dapat terlaksana dengan optimal dan berkelanjutan. WWF Indonesia berkolaborasi dengan PT. Bogatama Marinusa (PT. Bomar) berinisiatif melakukan program rehabilitasi mangrove sebagai salah satu dukungan sertifikasi produk udang berkelanjutan ASC (Aquaculture Stewardship Council).

\section{METODOLOGI}

\section{Waktu dan lokasi kegiatan}

Kegiatan ini dilaksanakan di dusun Binanga Sangkara, kecamatan Bontoa, kabupaten Maros, Sulawesi Selatan (Gambar 1). Waktu pelaksanaan kegiatan (persiapan hingga penanaman) dilakukan dalam empat tahap, dimulai sejak September 2019 hingga November 2020.

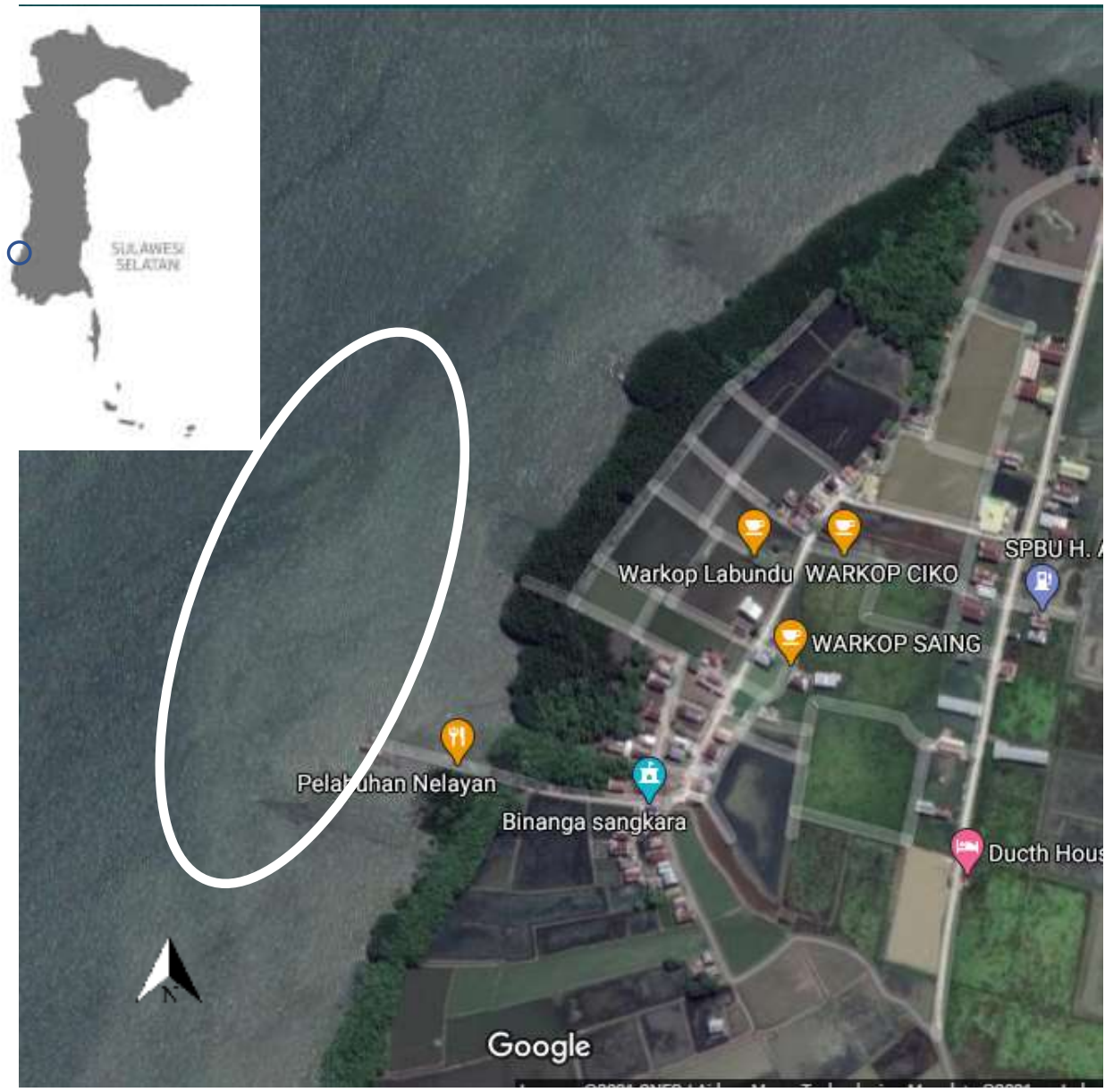


Gambar 1. Lokasi kegiatan penanaman mangrove di dusun Binanga Sangkara, Maros, Sulawesi Selatan

Rancangan kegiatan

Program penanaman mangrove ini menargetkan untuk rehabilitasi hingga 1 hektar luasan lahan target dengan menyediakan hingga 24.000 bibit pohon (Tabel 1).

Tabel 1. Waktu penanaman, target luasan, dan target pohon yang ditanam selama kegiatan

\begin{tabular}{ccc}
\hline Waktu penanaman & Target bibit & Target luasan \\
\hline 25 September 2019 & 3.000 pohon & $1.250 \mathrm{~m}^{2}$ \\
27 November 2019 & 3.000 pohon & $1.250 \mathrm{~m}^{2}$ \\
22 Desember 2019 & 8.000 pohon & $3.300 \mathrm{~m}^{2}$ \\
15 November 2020 & 10.000 pohon & $41.700 \mathrm{~m}^{2}$ \\
\hline
\end{tabular}

Dengan mengadaptasi konsep implementasi praktik rehabilitasi ekosistem mangrove berbasis eko-sosioekonomis yang dikemukakan oleh Biswas dkk. (2009), beberapa kompenen penting dalam merancang kegiatan rehabilitasi mangrove meliputi:

1. Identifikasi permasalahan dan tujuan rehabilitasi

2. Mensitesis kondisi ekosistem masa lalu dan sekarang, terutama struktur ekologi dan fungsinya dan ketergantungan masyarakat terhadap ekosistem mangrove

3. Menyusun garis besar rencana rehabilitasi yang sistematis (ecological engineering)

4. Mengembangkan keterlibatan masyarakat dan rencana subisdi pendapatan (economic-social engineering)
5. Mengembangkan rencana detil implementasi

6. Mengembangkan dan menerapkan mekanisme pengawasan yang ketat untuk manajemen adaptif yang logis.

\section{Metode pelaksanaan kegiatan}

Implementasi program penanaman dilakukan dengan beberapa tahapan :

1. Perencanaan, yaitu langkah pertama sebelum pelaksanaan program yang terdiri atas:

a. Survei lokasi yaitu melihat potensi lokasi di Binanga Sangkara yang akan menjadi sasaran untuk program penanaman mangrove.

b. Memastikan pelaksanaan program telah mendapat izin dan dukungan dari otoritas terkait setempat (pemerintah desa, Dinas 
Perikanan, Dinas Lingkungan Hidup).

c. Wawancara dan dengan masyarakat lokal yang representatif untuk mengidentifikasi potensi lokasi penanaman mangrove.

2. Konsolidasi dengan komunitas (pembentukan tim penanaman mangrove).

3. Sosialisasi dengan masyarakat untuk mendapat dukungan agar program tidak mengalami kendala yang bersinggungan dengan kepentingan masyarakat lokal hingga akhir.

4. Penanaman di lokasi,

\section{Analisis data}

Analisis hasil kegiatan dilakukan dengan memonitoring hasil penanaman setelah sekitar 3 (tiga) bulan pelaksanaan penanaman. Hal ini dilakukan untuk mengidentifikasi tingkat keberhasilan dan keberlanjutan mangrove yang telah ditanam. Hasil yang diperoleh dibahas secara deskriptif.

\section{HASIL DAN PEMBAHASAN}

\section{Gambaran kegiatan penanaman}

Penanaman mangrove tahap pertama dilakukan dengan disajikan bersama dengan Kemah Konservasi yang mengambil tema "Saya Menanam
Mangrove, Saya Memilih Bumi”. Kegiatan ini mengharapkan peserta kegiatan dapat memposisikan dirinya sebagai bagian dari penyelamat bumi. Sebelum penanaman dilakukan, pada malam hari diadakan pemaparan materi dan diskusi bersama peneliti BRPBAPPP Maros. Di hari penanaman, sebanyak 3.000 bibit jenis Rhizopora sp., 2.500 berupa propagul yang disiapkan oleh BRPBAPPP Maros dan 500 bibit yang telah tumbuh paling sedikit tiga daun yang juga disemai dan disiapkan oleh BRPBAPPP Maros dari Instalasi Tambak Percobaan Marana Maros, dieksekusi untuk ditanam bersama peserta. Peserta berasal dari mahasiswa magang UNHAS, siswa SUPM Bone, serta komunitaskomunitas pecinta alam asal Maros, Makassar, dan Pare-Pare dengan total peserta sebanyak 70 orang (Gambar 2).

Kegiatan penanaman kedua, WWF Indonesia mendapat respon positif dari salah satu universitas di Makassar yaitu Universitas Teknologi Sulawesi (UTS). UTS bersedia bergabung menjadi bagian dari program besar penanaman mangrove Bersama WWF Indonesia. WWF Indonesia membantu menyiapkan sebanyak 3.000 bibit dan ikut perpartisipasi dalam 
Journal of Aquaculture Science

DOI: https://doi.org/10.31093/joas.v6i1IS.166
July 2021 Vol 6 Issue Spesial: 134-147

Online pada http://joas.co.id penanaman yang dilaksanakan pada 27

November 2019 (Gambar 3). Bibit mangrove jenis Rhizopora sp. diperoleh dari pembibitan lokal desa Ampekale, Maros yang telah tumbuh daun paling sedikit tiga helai.

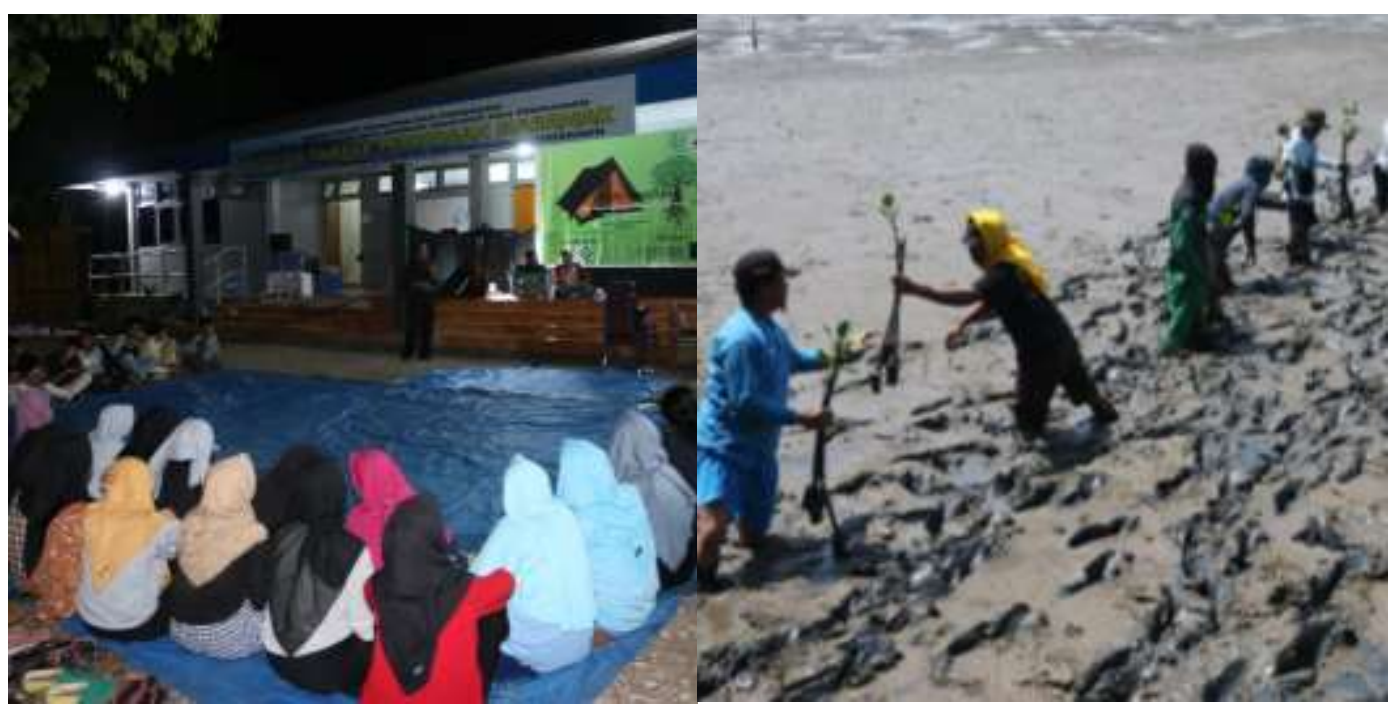

Gambar 2. Kegiatan Kemah Konservasi sebagai salah satu program penanaman mangrove tahap pertama (kiri) Pemaparan materi dan sesi diskusi Bersama ahli; (kanan) Penanaman mangrove di lokasi.

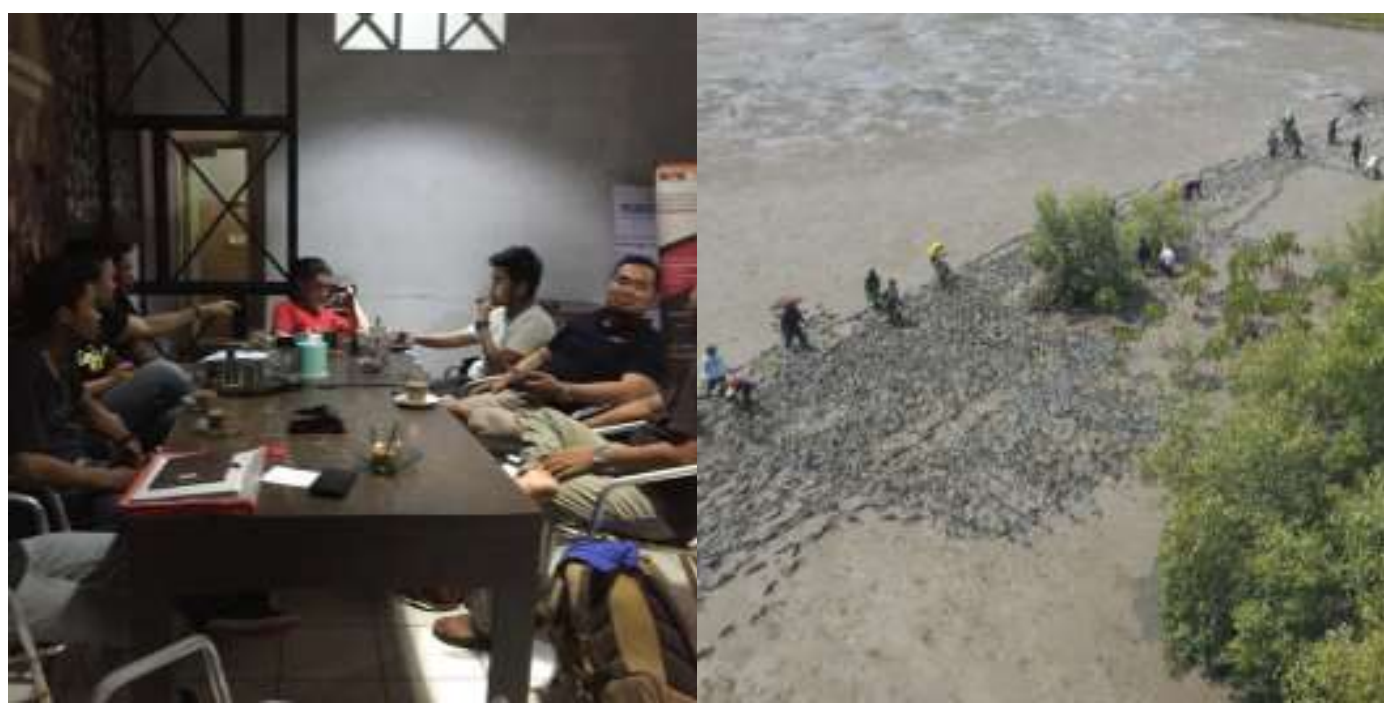

Gambar 3. (kiri) Diskusi rencana kerjasama WWF-Indonesia dan UTS (Universitas Teknologi Sulawesi) dalam penanaman 5.000 bibit mangrove. (kanan) Penanaman mangrove bersama UTS.

Penanaman mangrove tahap

tiga, WWF Indonesia bekerjasama dengan salah satu organisasi kepemudaan lokal KNPI Maros dan warga sekitar. Di kegiatan ini, sebanyak
8.000 bibit berhasil ditanam dengan menggunakan propagul. Bibit mangrove jenis Rhizopora sp. diperoleh dari bakau yang tumbuh subur di daerah Lakkang, Makassar (Gambar 4). 


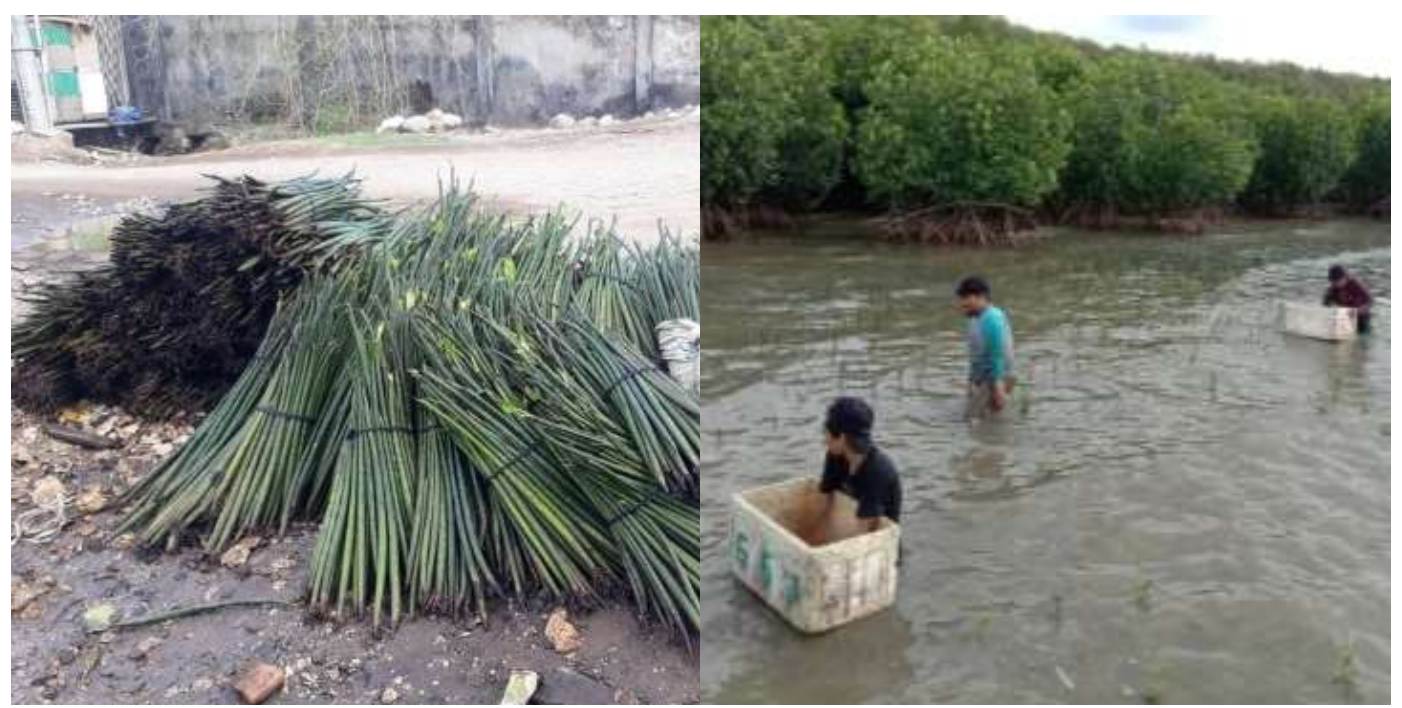

Gambar 4. (kiri) Bibit propagul yang digunakan untuk penanaman tahap tiga. (kanan) Proses penanaman bibit propagul di lokasi.

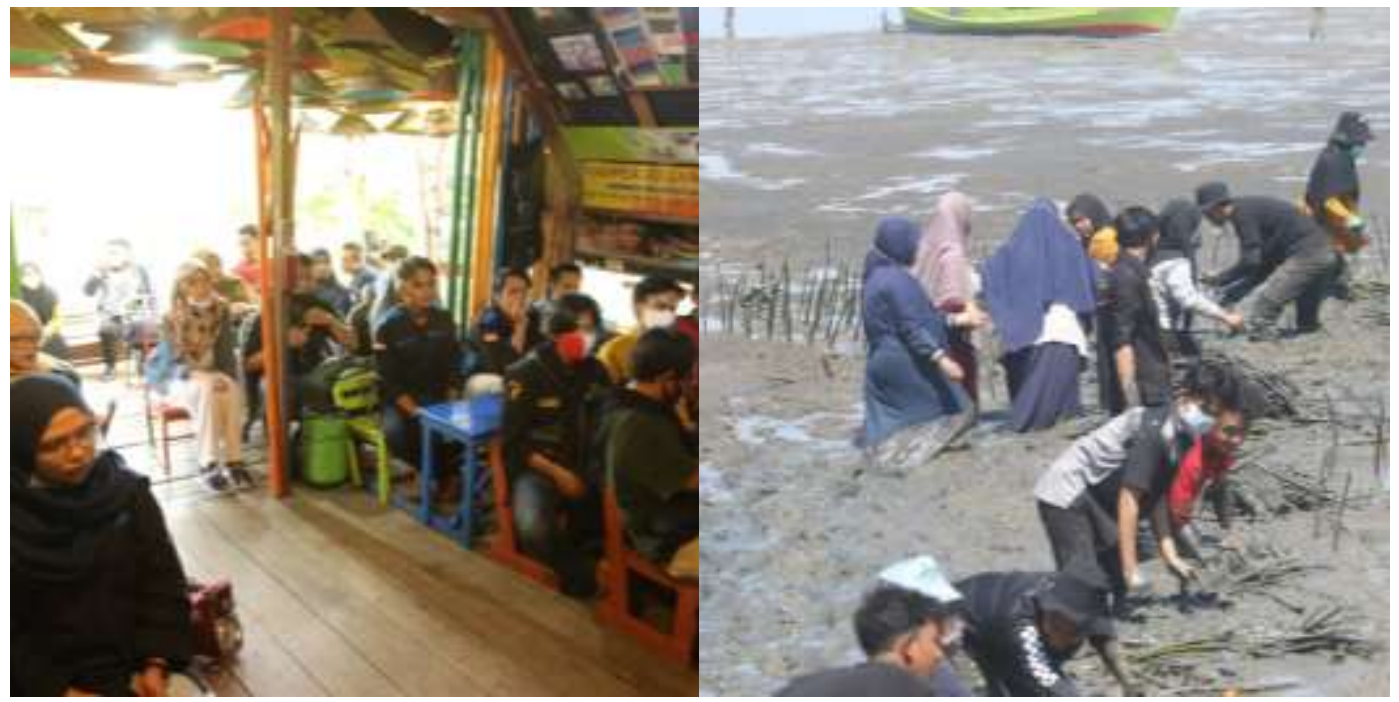

Gambar 5. (kiri) Diskusi brainstorming bersama komunitas pemuda Maros membahas isu lingkungan. (kanan) Proses penanaman bibit propagul di lokasi kegiatan.

\begin{abstract}
Kegiatan penanaman tahap empat, WWF-Indonesia dahulu menginisiasi terlebih diskusi
\end{abstract} brainstorming isu lingkungan bersama komunitas pemuda Maros. Keigatan ini awalnya sempat tertunda akibat pandemi COVID-19 hingga akhirnya dapat terlaksana pada 14-15 November 2020. Diskusi melibatkan 15 komunitas pemuda Maros dan juga mengundang seorang aktivis lingkungan asal Maros sebagai pengantar diskusi lingkungan di Maros. Berbagai data permasalahanpermasalahan lingkungan yang ada di Kabupaten Maros berhasil teridentifikasi bersama peserta kegiatan selama diskusi berlangsung seperti isu sampah, penebangan mangrove, inisiasi aksi tanam pohon, hingga isu plastik sekali pakai. Isu-isu teridentifikasi 
tersebut selanjutnya dibahas lebih lanjut melalui jejaring media sosial yang dibuat untuk memfasilitasi komunitas pemuda Maros bergerak untuk perbaikan lingkungan (Maros Ekologi). Di hari berikutnya, sebanyak 10.000 bibit mangrove jenis Rhizopora sp. asal Lakkang, Makassar berhasil ditanam bersama 60 relawan yang berasal dari Ikatan Pelajar Muhammadiyah (IPM) Maros dan beberapa komunitas pemuda Maros lainnya (Gambar 5). Secara keseluruhan, lokasi keempat tahap penanaman mangrove di Binanga Sangkara kabupaten Maros tersaji pada gambar 6.

\section{Hasil monitoring}

Hasil monitoring kelulushidupan mangrove yang telah ditanam pada empat tahap program penanaman dapat dilihat pada Tabel 2. Berdasarkan hasil monitoring, mayoritas mangrove yang ditanam telah berhasil bertahan hidup, ditunjukkan dengan tingginya angka kelulushidupan di keempat tahap kegiatan. Secara keseluruhan, kelulushidupan mangrove yang telah ditanam dari keempat tahap penanaman mencapai $74 \%$. Namun, terdapat satu tahap penanaman yang memiliki tingat kelulushidupan yang rendah, yaitu hanya $5 \%$. Hal ini diduga karena bibit yang digunakan memiliki kualitas yang rendah. Penurunan kualitas bibit dapat disebabkan oleh beberapa kemungkinan seperti bibit yang tidak segera ditangani saat tiba sebelum ditanam, perlakuan bibit yang akan ditanam yang tidak optimal, dan waktu penyimpanan saat transportasi bibit yang telalu lama (Wisibino dkk., 2006; Rizki dan Novi, 2017). Akibatnya, bibit tidak dapat bertahan pada kondisi lokasi penanaman sehingga akhirnya mempengaruhi keberhasilan penanaman.

Secara keseluruhan, program penanaman mangrove di Binanga Sangkara memiliki angka kelulushidupan yang tinggi. Beberapa program penanaman mangrove lainnya yang telah dilakukan di beberapa lokasi seperti Pesisir Pulau Untung Jawa Kepulauan Seribu (Winata dan Yuliana, 2016) dengan kelulushidupan $72 \%$, beberapa lokasi di Sulawesi Utara Sulawesi Utara (Arifin dkk., 2019) dengan kelulushidupan di bawah 50\%, dan di Seram Barat Maluku (Makaruku dan Aliman, 2019) dengan kelulushidupan di bawah $70 \%$. Penentuan lokasi diduga dapat menjadi faktor pendukung keberhasilan pelaksanaan penanaman mangrove di Binanga Sangkara. Lokasi penanaman 
Journal of Aquaculture Science

DOI: https://doi.org/10.31093/joas.v6i1IS.166

di Binanga Sangkara ditentukan dengan

mengidentifikasi berdasarkan sejarah

lokasi, termasuk jenis pohon yang dominan pernah menutupi kawasan tersebut dengan melibatkan masyarakat
July 2021 Vol 6 Issue Spesial: 134-147

Online pada http://joas.co.id

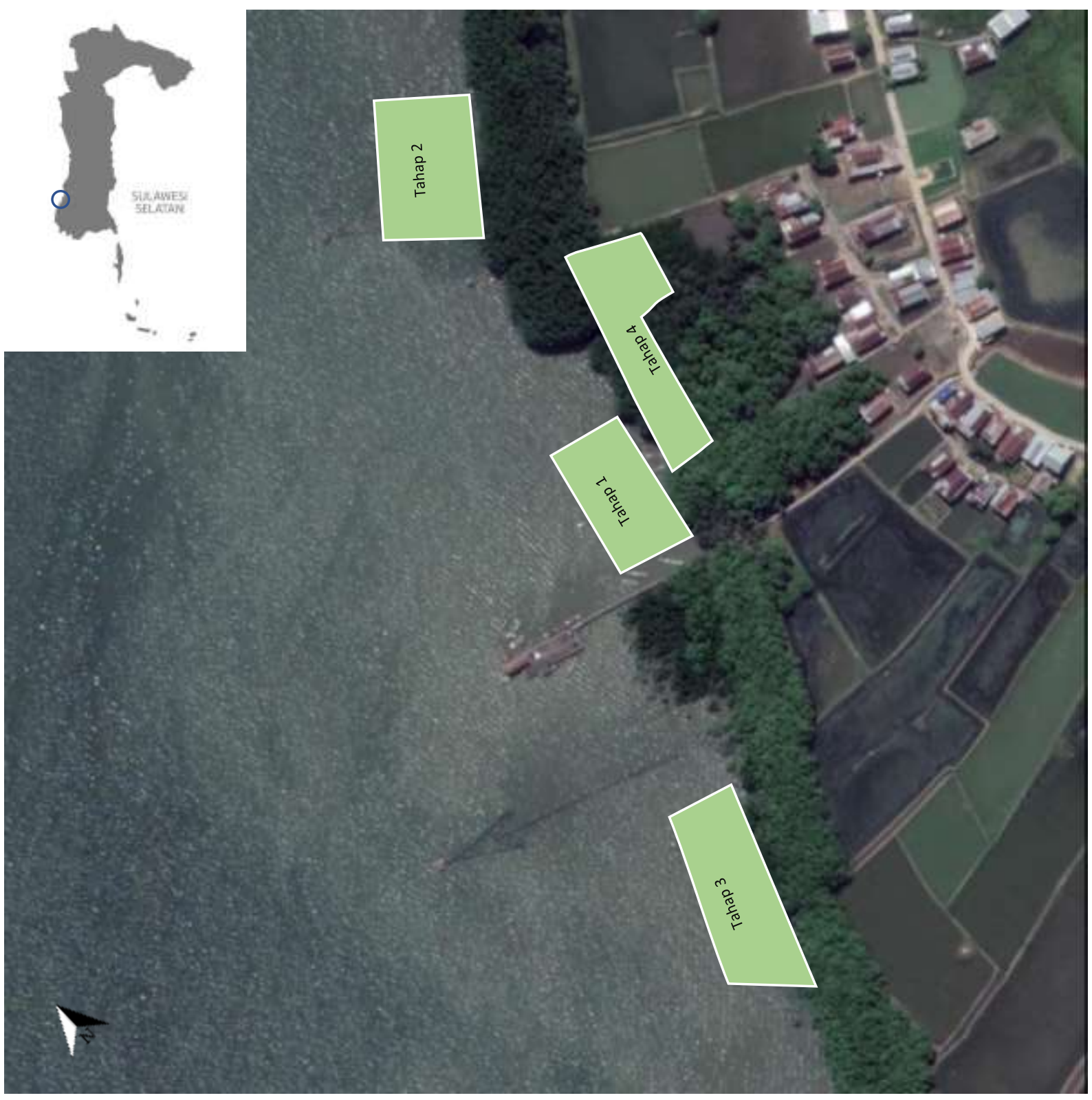

Gambar 6. Peta lokasi penanaman mangrove pada setiap tahapan di Binanga Sangkara, Maros, Sulawesi Selatan (arsiran hijau).

setempat. Hal ini penting dilakukan karena dengan mengetahui sejarah lokasi, strategi penanaman mangrove dapat dilakukan secara lebih optimal. 
Tabel 2.Hasil monitoring kelulushidupan bibit mangrove yang telah ditanam di dusun Binanga Sangkara, Maros, Sulawesi Selatan.

\begin{tabular}{cccc}
\hline Waktu penanaman & Pohon tertanam & Waktu monitoring & Kelulushidupan \\
\hline $25-09-2019$ & 3.000 pohon & $2-3-2020$ & $90 \%$ \\
$27-11-2019$ & 3.000 pohon & $2-3-2020$ & $5 \%$ \\
$22-12-2019$ & 8.000 pohon & $2-3-2020$ & $80 \%$ \\
$15-11-2020$ & 10.000 pohon & $17-2-2021$ & $85 \%$ \\
Total & 24.000 pohon & & $74 \%$ \\
\hline
\end{tabular}

\section{Keterlibatan komunitas pemuda setempat dan institusi lainnya}

Keterlibatan komunitas pemuda dan institusi lainnya pada kegiatan penanaman mangrove di Binanga Sangkara, Maros dapat dilihat pada Tabel 3. Pada kegiatan penanaman pertama, komunitas pemuda diajak untuk turut serta dalam suatu rangkaian acara kemah konservasi yang diselingi sesi diskusi bersama. Penanaman keempat juga diawali dengan sesi pemaparan materi dan diskusi kepada peserta. Sesi diskusi juga mengundang ahli dari BRPBAPPP Maros dan aktivis lingkungan senior Maros. Dengan menyajikan kegiatan seperti ini, program penanaman mangrove berhasil menarik minat banyak komunitas pemuda untuk menjadi peserta. Selain itu, penyajian kegiatan dengan diskusi bersama dapat memicu minat dan kepedulian peserta untuk lebih peduli terhadap lingkungan, terutama pentingnya peran mangrove bagi perikanan dan masyarakat pesisir.

Tabel 3. Jumlah komunitas pemuda dan peserta yang berpartisipasi dalam kegiatan penanaman mangrove di Binanga Sangkara Maros.

\begin{tabular}{ccc}
\hline Waktu penanaman & Jumlah Komunitas/Institusi & Jumlah Peserta \\
\hline 22 September 2019 & 10 & 80 orang \\
27 November 2019 & 4 & 30 orang \\
22 Desember 2019 & 3 & 10 orang \\
15 November 2020 & 15 & 70 orang \\
\hline
\end{tabular}

Diskusi kritis berpotensi menjadi salah satu metode yang dapat menarik perhatian pemuda untuk dapat terlibat dalam kegiatan rehabilitasi lingkungan dan meningkatkan kesadaran berpikir pemuda terkait urgensi upaya penyelamatan lingkungan. Diskusi kritis dapat menjadi ajang bertukar pikirian untuk dapat berbagi pengetahuan (share of knowledge) hingga lebih lanjut dapat menyelesaikan permasalahan bersama dari akumulasi informasi dan pengetahuan yang diperoleh (Parker dan 
Hess, 2000). Akumulasi pengetahuan yang terjadi dapat menjadi sarana mengembangkan pengetahuan lebih lanjut (Sohail dan Daud, 2009; Buckley, 2012) dan pada akhirnya memicu kesadaran berpikir untuk dapat bertindak lebih bijaksana.

Selain dengan menyajikan rangkaian kegiatan dalam penanaman mangrove, dua tahap penanaman juga dilakukan dengan inisiasi dari komunitas maupun universitas untuk melakukan penanaman. Hal ini semakin memperlihatkan kepedulian pemuda yang semakin meningkat akan pentingnya menjaga ekosistem mangrove. Menurut Nugroho (2017), bentuk kepedulian pemuda, terutama mahasiswa, dapat bermula dari berbagai aktivitas organisasi mereka yang secara aktif mendiskusikan isu-isu penting di masyarakat, termasuk isu terkait lingkungan. Pemuda Indonesia pun tidak mau kalah untuk melakukan aksi peduli lingkungan dengan berbagai bentuk yang secara bersama-sama bergerak melalui organisasi pergerakan berorientasi lingkungan (organized/voluntary environmentalist). Inisiatif organisasi kemahasiswaan maupun kepemudaan berkolaborasi dengan lembaga non pemerintah terkait lingkungan dapat menjadi salah satu gambaran aktualisasi dari apa yang mereka dapatkan selama berproses dalam organisasi mahasiswa/pemuda. Banyak organisasi kepemudaan telah mengaktualisasikan aksi kepeduliannya terhadap lingkungan dengan berbagai format, baik dalam bentuk jaringan (networking) hingga berafiliasi dengan lembaga konservasi pemerintah, nasional, hingga internasional (Suharko dkk., 2014).

\section{KESIMPULAN}

Berdasarkan hasil kegiatan, program penanaman mangrove di dusun Binanga Sangkara telah berhasil menanam sebanyak 24.000 bibit jenis Rhizopora sp. dengan kelulushidupan yang tinggi mencapai $74 \%$. Program penanaman ini juga telah mengajak berbagai komunitas pemuda lokal hingga institusi terkait untuk dapat terlibat aktif dan meningkatkan kesadaran serta berinisiatif untuk bertindak menjaga dan melestarikan lingkungan, terutama tentang pentingnya menjaga kawasan mangrove demi masa depan perikanan dan masyarakat pesisir. Untuk pelaksanaan kegiatan serupa, perlu mempertimbangkan sejarah lokasi, pengorganisasian yang matang, dan 
keterlibatan aparat terkait setempat serta masyarakat setempat demi keberlanjutan kawasan mangrove yang direhabilitasi.

\section{Ucapan Terima Kasih}

Penulis ingin menyampaikan terimakasih kepada Balai Riset Budidaya Air Payau dan Penyuluhan Perikanan (BRBAPPP) Maros, Universitas Teknologi Sulawesi, Aquaculture Celebes Community, Ikatan Pelajar Muhammadiyah (IPM) Maros, dan seluruh pihak yang tidak dapat kami sebutkan satu per satu atas kontribusi dan semangat dalam implementasi program penanaman mangrove di Binanga Sangkara.

\section{DAFTAR PUSTAKA}

Anggraeni, M., Rustiadi, E., dan Yulianto, G. (2020). Peranan Sektor Perikanan Terhadap Perekonomian Kabupaten Natuna. Jurnal Kebijakan Sosial Ekonomi Kelautan dan Perikanan, 10(1): 11-23.

Arifin, M. Z., Mulalinda, P., Kalesaran, J., Tauladani, S., dan Asia, A. (2019). Studi Tingkat Keberhasilan Penanaman Mangrove di Pesisir Desa Dagho, Kabupaten Kepulauan Sangihe, Desa Matahit Kabupaten Kepulauan Talaud dan Kelurahan Pasirpanjang, Kecamatan Lembeh Selatan, Kota Bitung. Frontiers: Jurnal Sains Dan Teknologi, 2(1).

Asiati, D., dan Nawawi, N. F. N. (2017). Kemitraan Di Sektor Perikanan Tangkap: Strategi untuk Kelangsungan Usaha dan Pekerjaan. Jurnal Kependudukan Indonesia, 11(2): 103-118.
Badan Pusat Statistik Provinsi Sulawesi Selatan (2019). Statistik Provinsi Sulawesi Selatan Dalam Angka. BPS Sulsel.

Nugroho, A. (2017). Geliat Organisasi Pemuda Lingkungan (Opl) Dalam Ranah Gerakan Lingkungan Di Yogyakarta. Jurnal Sosiologi Agama, 9(1): 190-148.

Bappenas (2014). Kajian Strategi Pengelolaan Perikanan Berkelanjutan. Jakarta (ID): Bappenas.

Biswas, S. R., Mallik, A. U., Choudhury, J. K., dan Nishat, A. (2009). A unified framework for the restoration of Southeast Asian mangrovesbridging ecology, society and economics. Wetlands Ecology and Management, 17(4): 365-383.

Buckley, S. (2012). Higher Education and Knowledge Sharing: From Ivory Tower to Twenty-first Century. Innovations in Education and Teaching international, Vol. 49(3): 333-344.

Suharko, Alam, M., Madya, S.H., Prastowo, F.R., dan Nugroho, A. (2014). Organisasi Pemuda Lingkungan di Indonesia Pasca-Orde Baru, Gadjah Mada University Press, Yogyakarta.

FAO (1982). Management and Utilization of Mangrove in Asia and the Pacific. Rome: FAO Environment Paper 3.

Fitri, R.Y. dan Anwar, K. (2014). Kebijakan Pemerintah terhadap Pelestarian Hutan Mangrove di Kecamatan Tebing Tinggi Kabupaten Bengkalis. Jom FISIP 1(2):1-15.

Giesen, W., Wulffraat, S., Zieren, M., Scholten, L. (2007). Mangrove guidebook for Southeast Asia. FAO Regional Office for Asia and the Pacific, Bangkok.

Hafni, R. (2016). Analisis Dampak Rehabilitasi Hutan Mangrove terhadap Pendapatan Masyarakat Desa Lubuk Kertang Kabupaten Langkat. Jurnal Ekonomikawan, 16(2): 78262.

Makaruku, A., dan Aliman, R. (2019). Analisis Tingkat Keberhasilan Rehabilitasi Mangrove Di Desa Piru Kecamatan Seram Barat Kabupaten Seram Bagian Barat. Jurnal Rekayasa Lingkungan, 19(2).

Manassrisuksi, K., M. Weir, and Y.A. Hussin (2001). Assesment of mangrove 
Journal of Aquaculture Science

DOI: https://doi.org/10.31093/joas.v6i1IS.166
July 2021 Vol 6 Issue Spesial: 134-147

Online pada http://joas.co.id

and Institute for Environmental Studies

remote sensing and GIS: a case study

of Amphur Khlung, Chantaburi

Province, Eastern Thailand. 22nd

Asian Conference on Remote

Sensisng, Singapore 5-9 November 2001

Ong, J.E (2002). The hidden costs of mangrove services: use of mangroves for shrimp aquaculture. International Science Round Table for the Media, Bali Indonesia, 4 June 2002. Joint event of ICSU, IGBP, IHDP, WCRP, DIVERSITAS and START.

Parker, W.C. dan Hess, D. (2000). Teaching with and for Discussion. Teaching and Teacher Education, 17: 273-289

Rizki, R., dan Novi, N. (2017). Respon pertumbuhan bibit mangrove Rhizophora apiculata B1 pada media tanah top soil. Jurnal Bioconcetta, 3(2), 41-54.

Setiawan, H. (2015). Studi pengelolaan hutan mangrove sebagai bahan baku industri arang di Pulau Tanakeke Kabupaten Takalar Sulawesi Selatan. In Seminar Nasional Sewindu BPTHHBK Mataram: Pengarusutamaan Hasil Litbang Lingkungan Hidup dan Kehutanan sebagai Lokomotif Pembangunan Berkelanjutan (pp. 597-605).

Setyawan, A.D., Winarno, K., dan Purnama, P.C. (2003). Ekosistem Mangrove di Jawa: 1. Kondisi Terkini. Biodiversitas,4,(2): 130-142

Sohail, M.S. dan Daud, S. (2009). Knowledge Sharing in Higher Education Institutions: Perspectives from Malaysia. The Journal of Information and Knowledge Management Systems, 39(2): 125-142

Spalding, M., Blasco, F., dan Field, C. (1997). World Mangrove Atlas. Okinawa: International Society for Mangrove Ecosystems.

Spaninks, F. and P. van Beukering (1997). Economic Valuation of Mangrove Ecosystems: Potential and Limitations. CREED Working Paper No 14, July 1997. London and Amsterdam: International Institute for Environment and Development, dan Ekariyo, W. (1996). Penghijauan pantai. PT. Penebar Swadaya, Jakarta.

Supriharyono (2007). Konservasi Ekosistem Sumberdaya Hayati Di Wilayah Pesisir dan Laut Tropis, Pustaka Pelajar, Yogyakarta.

Syamsu, I. F., nugraha, A. Z., nugraheni, C. T., dan Wahwakhi, S. (2018). Kajian perubahan tutupan lahan di ekosistem mangrove Pantai Timur Surabaya. Media Konservasi,23(2): 122-131.

Wibisono, I.T.C., Priyanto, E.B., Suryadiputra, I.N.N. (2006). Panduan Praktis Rehabilitasi Pantai. Wetlands International Indonesia Programme, Bogor, Indonesia.

Winata, A., dan Yuliana, E. (2016). Tingkat keberhasilan penanaman pohon mangrove (kasus: pesisir Pulau Untung Jawa Kepulauan Seribu). Jurnal Matematika Sains dan Teknologi, 17(1): 29-39. 